DOI https://doi.org/10.30525/978-9934-588-79-2-1.20

\title{
ОСОБЛИВОСТІ ПІДГОТОВКИ ЛЮДЕЙ 3 ОБМЕЖЕНИМИ ФІЗИЧНИМИ МОЖЛИВОСТЯМИ ЗАСОБАМИ ЦИФРОВИХ ТЕХНОЛОГІЙ
}

\author{
Твердохліб О. С. \\ доктор наук з державного управління, доцент, \\ професор кафедри державного управління у сфері иивільного захисту \\ Інституту державного управління та наукових досліджень \\ з ицивільного захисту, \\ професор кафедри стратегічних комунікаиій \\ Національного університету оборони України \\ імені Івана Черняховського \\ м. Київ, Украӥна
}

В умовах сьогодення перед сучасним суспільством постає непросте завдання кардинальної зміни ставлення до людей з обмеженими фізичними можливостями шляхом створення для цієї категорії осіб сприятливих умов для самореалізації й самовдосконалення, рівноправних можливостей, розроблення та впровадження різних методів i заходів, що дозволяють їм повноцінно освоювати соціальний досвід, існуючу систему суспільних відносин. 3 цією метою формується система ефективної соціальної підтримки, що включає соціальні, медичні, педагогічні, психологічні аспекти їхньої реабілітації, які дозволяють людям з обмеженими фізичними можливостями нарівні входити в суспільство здорових людей та повноцінно інтегруватися в нього.

Упродовж останніх десятиліть соціальна політика багатьох європейських країн стосовно осіб з обмеженими фізичними можливостями зазнала суттєвих змін. Ставлення до цієї соціальної групи людей як до пацієнтів, якими необхідно лише опікуватися, і які не можуть долучатися до активного суспільного життя, змінилося на ставлення до них як до повноправних членів суспільства, що мають однакові права 3 іншими громадянами країни $[1$, c. 5].

Наразі цивілізовані країни намагаються вирішити соціальні проблеми, пов'язані зі зростанням кількості осіб з обмеженими фізичними можливостями, з урахуванням науково обгрунтованих підходів, застосуванням матеріально-технічних засобів, детально розроблених юридичних механізмів, загальнонаціональних програм та громадських ініціатив, високого рівня професійної підготовки фахівців. 
Основною метою державної соціальної політики щодо осіб з інвалідністю в Україні є забезпечення рівних можливостей та реалізація конституційних прав цією категорією громадян, створення сприятливих правових, політичних, соціально-економічних, медичних, психологічних, організаційних умов і гарантій для їх інтеграції у суспільне життя. Адже фізичний, сенсорний чи інтелектуально-психологічний недоліки можуть ізолювати їх від суспільства, заважати їм самостійно пересуватися, орієнтуватися в просторі та унеможливлюють на рівні 3 фізично здоровими людьми брати участь у житті суспільства.

Людям з обмеженими фізичними можливостями необхідні умови для самореалізації, адже вони у своїй більшості є сильними і вольовими особистостями, які здатні навчатися, працювати і вдосконалюватися. Однак повною мірою реалізувати себе вони зможуть лише за наявності елементарних умов, у першу чергу законодавчих і побутових.

Урядом України прийнято рішення щодо всезагальної цифровізації, цифрової трансформації суспільства, що нині стає чи не ключовим фактором, який впливає буквально на всі суспільні процеси - від повсякденних до глобальних. Тому й держави, які нехтують цим, ризикують втратити свої позиції не лише в IT-сфері, а й у інших галузях економічній, фінансовій, гуманітарній тощо.

Саме цифрові технології в значній мірі можуть стимулювати розвиток відкритого інформаційного суспільства як одного з істотних факторів розвитку демократії в Україні, підвищення продуктивності, економічного зростання, створення робочих місць, а також підвищення якості життя громадян України. У цьому контексті актуалізуються питання нових форм солідарності, партнерства і співробітництва.

Застосування цифрових технологій в освітній сфері є сьогодні однією 3 найбільш важливих і стійких тенденцій розвитку світового освітнього процесу. Вони дозволяють інтенсифікувати процес навчання, збільшити швидкість та якість сприйняття, розуміння і засвоєння знань. За допомогою новітніх інтерактивних засобів навчання застосовується підхід до викладання на основі впровадження інноваційних методик, засобів і методів, включаючи використання кейсів, дослідницько-пошукової роботи, проектування, розвиваючих навчальних ігор тощо.

У всьому світі, у тому числі й у нашій країні, тривалий час існувала сегрегативна модель навчання осіб з інвалідністю, що передбачала навчання цих верств населення у спеціальних навчальних закладах. Така модель штучно позбавляла їх можливостей перебувати у звичайному оточенні, серед своїх однолітків, які не мають проблем зі здоров'ям. 
Протягом останніх років за рекомендаціями ЮНЕСКО у багатьох країнах світу модель навчання осіб з обмеженими фізичними можливостями було змінено зі сегрегативної на інклюзивну, що передбачає організацію спільного навчання інвалідів та осіб без інвалідності у навчальних закладах шляхом створення необхідних умов для такого навчання (індивідуалізації та адаптації навчальних планів (програм) до потреб і можливостей осіб з інвалідністю, пристосування основного та додаткового навчального обладнання, забезпечення архітектурної доступності до навчального закладу тощо) [3, с. 93].

Новітні цифрові технології нині дозволяють зробити процес навчання мобільним, диференційованим та індивідуальним. При цьому технології не замінюють педагога, а доповнюють його. Заняттям, побудованим на базі сучасних цифрових технологій, властиві адаптивність, керованість, інтерактивність, поєднання індивідуальної та групової роботи, часова необмеженість навчання. Відповідно, особа 3 особливими потребами може ефективно планувати свою діяльність, визначати цілі і завдання відповідно до власних можливостей і потреб. Не зважаючи на географічну дистанційованість і неможливість відвідувати освітні установи внаслідок хвороби, інвалід завдяки навчанню в дистанційному форматі отримує якісну освіту, що поєднує в собі індивідуалізований підхід і методи традиційної освіти.

На відміну від заочної форми здобуття освіти, дистанційне навчання осіб з обмеженими фізичними можливостями дозволяє більш ефективно підійти до організації навчального процесу. Теми, методи і обсяг навчального матеріалу підбираються індивідуально, що дозволяє вибудовувати ефективну систему навчання та сприяє побудові індивідуальної освітньої траєкторії здобувачів освіти.

Світовий процес переходу до інформаційного суспільства, а також економічні, політичні та соціальні зміни, що його супроводжують, значною мірою прискорюють реформування системи освіти. Перш за все це стосується забезпечення доступу до освіти для тих людей, які його не мали раніше, а особливо для осіб з обмеженими фізичними можливостями. Адже саме ці люди, як правило, під час навчання у спеціальних навчальних закладах або вдома не отримують необхідних вмінь і навичок, потрібних для повноцінного життя в суспільстві. Тому впровадження альтернативних форм навчання для людей 3 особливими потребами $є$ найбільш необхідним в сучасному світі, оскільки новітні технології забезпечують доступ до інформаційного простору та освіти без кордонів.

Саме освіта сприяє розвитку людини як особистості та найвищої цінності суспільства, розвитку ії талантів, розумових і фізичних здіб- 
ностей, вихованню високих моральних якостей, формуванню громадян, здатних до свідомого суспільного вибору, спроможних приносити користь суспільству [2, с. 120]. Ставлення до людей з особливими потребами в сучасному світі виступає не лише мірилом людяності і толерантності в суспільстві, але й системної істинності його поглядів.

\section{Література:}

1. Байда Л., Красюкова-Енс О., Буров С. [та ін.]. Інвалідність та суспільство : навч. пос. / за заг. ред. Л. Байди, О. Красюкової-Енс ; Канад. центр вивчення неповносправності, ВГСПО «Нац. Асамблея інвалідів України». Київ: [ВПЦ «Київ. ун-т»], 2012. 187 с.

2. Мігалуш А. О. Дистанційна освіта для людей з особливими потребами: проблеми та шляхи їх подолання. Вісн. НТУУ «КПІ». Філософія. Психологія. Педагогіка : зб. наук. пр. / М-во освіти і науки України, Нац. техн. ун-т України. Київ: Політехніка, 2007. № 2 (20), ч. 2. С. $118-121$.

3. Про становище інвалідів в Україні : нац. доповідь / Мінсоцполітики України, ДУ НДІ соц.-труд. відносин Мінпраці України, Нац. Асамблея інвалідів України. Київ, 2008. 205 с.

DOI https://doi.org/10.30525/978-9934-588-79-2-1.21

\section{ЗАХИСТ ІНФОРМАЦЇ̈ ПРИ ТЕЛЕФОННИХ ПЕРЕГОВОРАХ ШЛЯХОМ СКРЕМБЛЮВАННЯ МОВНОГО СИГНАЛУ}

Триснюк В. М.

доктор технічних наук, старший науковий співробітник, завідувач відділу досліджень навколишнього середовища Інституту телекомунікаиій і глобального інформаційного простору Національної академії наук Украӥни

м. Київ, Украӥна

Сметанін К. В. кандидат технічних наук, викладач кафедри захисту інформації та кібербезпеки Житомирського військового інституту імені С. П. Корольова м. Житомир, Украӥна 